\title{
THE DEVELOPMENT OF RAILWAY CORPORATE STRUCTURES
}

\author{
J. W. BARRIGRR, III*
}

The story behind the capital structures of present day American railway systems is composed of elaborate corporate genealogies, in which are recorded the "vital statistics" of numberless corporate births, deaths, marriages, and divorces, each the joint issue of legal and financial procedure.

The Northern Pacific Railway Company is the only major carrier in the United States which was originally projected over the entire length of the territory which it now serves. All others are so essentially the products of consolidation that a modern system's pattern and extent bears only accidental resemblance to the original project out of which it has developed. As a result of this, and of the financial reorganizations which have befallen so many companies, most of the railway mileage of the country is owned or operated today by some corporation other than its builder. It follows that the present financial and corporate structures of most large railway systems, like their corporate genealogies, are exceedingly complex. They have grown so neither by accident nor design, but by force of circumstance.

The century which saw the United States expand territorially from a narrow strip of settlements along the Atlantic seaboard into a nation of continental proportions, also saw that nation's economic development keep pace with its territorial expansion principally because capital, enterprise and labor were directed toward the development of its inland transportation facilities. The continued development of these facilities is possible only so long as they remain in private hands, and the railroads will do this just so long as they are permitted to earn their own way and thereby remain attractive to private capital and individual enterprise.

A railway company derives its earnings from two scurces. Primarily, it looks to the profit from transportation it produces and sells. Supplementing that source is its income from its noncarrier operations and from its investments in properties which it owns but others operate, and from securities which it holds in companies operated by others. A carrier's profit from its transportation activities is termed its "net railway operating income." The "other income" which it receives is, naturally enough,

- B.S., I921, Massachusetts Institute of Technology. Chief Examiner, Railroad Division, Reconstruction Finance Corporation, since 1933. With the firm of Calvin Bullock, 1929-1933; with Kuhn, Loeb \& Co., 1927-1929; with the Pennsylvania R. R., 1921-1929. Collaborated with Mr. F. H. Prince of Boston in preparation of the Prince Plan of Railroad Consolidation. 
referred to as such.1 The sum, then, of "net railway operating income" and "other income" constitutes a carrier's "gross income," which is the earnings available for payment of the charges incurred in the hiring of the money necessary to implement its original "enterprise" capital, or for payment for the use of property leased from others. Any remainder of a carrier's gross income is, of course, available for distribution to those who hold the shares representing the enterprise capital.

Every large railway company uses a substantial amount of property in the performance of its carrier and non-carrier services to which it does not hold the title as owner. It may obtain the exclusive use of such property cither through stock control of the owning company, by lease, or by a combination of these methods. It may also arrange through various operating contracts or agreements for the joint or exclusive use of tracks, terminals or other facilities of companies which it neither owns nor controls. These are the devices by which the component properties in each railway system are knit together.

A railway system is, then, a group of corporations owning tangible and intangible assets producing earning power through the realization of "operating profits" and "other income", ultimately for a single corporation which may be termed the "parent company." The "corporate structure" of a railway system is builded from the corporate and financial devices by which the functions and earnings of these separate properties are integrated, and has significance mainly for purposes of administration, accounting and finance.

The "financial structure" of a railway system is a correlation of the capital structures of the several corporations comprising its corporate structure to show (a) the inter-system holdings of every security issue, which are the principal basis of integrating the corporate structure (except to the extent that leases, operating agreements and trackage rights do not necessitate security ownership for such use of property) and (b) the amount of every security issue held by the public. A complex system corporate structure invariably produces a complex system financial structure. Moreover, a complex financial structure of any single railway company invariably has resulted from past corporate complexities, even though the latter may have been simplified meanwhile through mergers, but which have left divisional bonds either, or both, held by the public or by the parent company as a continuing reminder of the past existence of demised corporations. The simplification of financial structures, which is always desirable, must be sought through refunding outstanding underlying bonds at maturity or by redemption (but the latter is seldom possible as a call provision for bonds is a relatively new financial feature and one seldom found in outstanding issues of this character) or through exchange or in reorganization if the latter becomes necessary.

\footnotetext{
2 The source of most "other income" is the transportation profit, i.e., net railway operating income, of some other railway operating company which the latter disburses as interest or dividends on securities or rental for property. Occasionally, as in the case of the Pennsylvania, a substantial part of the rentals which a lessee pays to lessors is returned to the former as a security bolder of the latter, either directly or through an affiated corporation, such as the Pennsylvaniz Co.
} 
The first annual report of the Interstate Commerce Commission, which was for the year 1887 , stated that the 133,605 miles of railroad then in operation were owned by 1,425 separate companies. At the turn of the century, there were 2,049 railroad companies owning 189,295 miles of road. Since that date the trend of development has been toward simplification, but, at the end of 1938 , ownership of the 236,842 miles of railway in the United States was divided among 1,389 railway companies, of which only 136 were Class I operating companies.

Table I.-Milles of Rond Owned and Operated by the Several Classes of Steam Rallonds as of Dec. 31, 1938

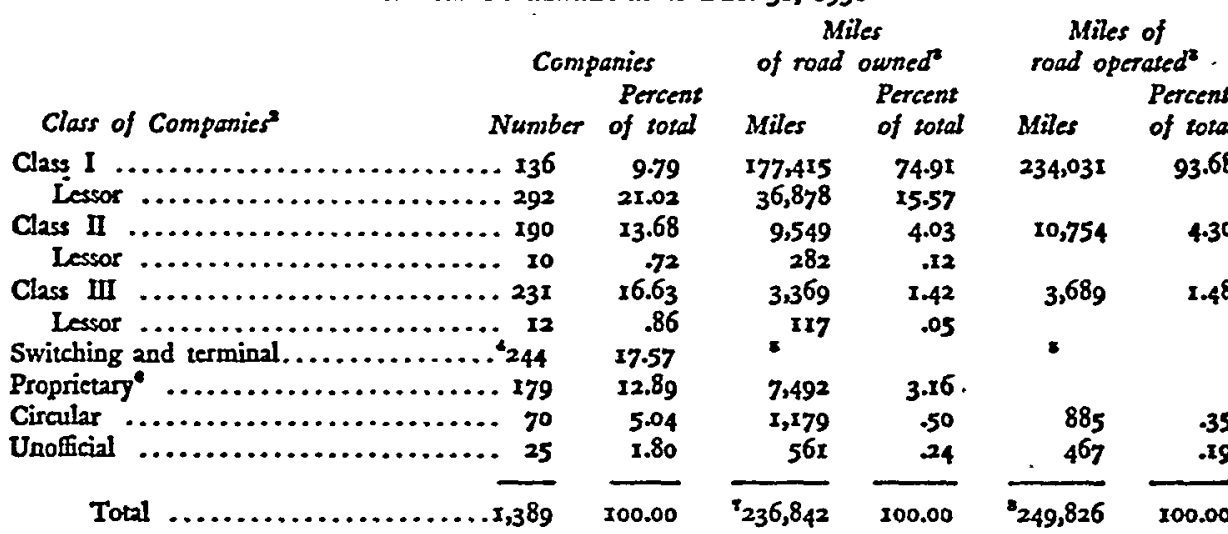

1 According to the I. C. C.'s Acconnting Classification, Class I railroads have annual operating revenuea in excess of $\$ 1,000,000$, Class II railroads, from $\$ 100,000$ to $\$ 1,000,000$, and Class III railroads, less than $\$ 100,000$.

2"Steam railway operating companies are those whose officers direct the actual transportation -service and Whose books contain operating as well as fnancial accounts. Lessor companies maintain a separate legal existence, but their properties are operated by the lessees, who may or may not be financiall interested in existence, but their properties are operated by the lessees, who may or may not be financially interested in the securities of the lessors. The reports of lessor companies contain only financial accounts. Proprietary that their outstanding capitalization is owned by the othet railway companies. If the entire capitalization of 2 lessor company is oprned, it is a proprietary as well as a lessor. If the proprietary is $a$ non-operating company, it is excused by the Commission's rules from filing a separate report and information regarding their mileage, investment, and capitalization appears in the reports of the companies operating their property. If a property is also $2 n$ operating company, it is required to make a separate operating report even though its capitalization is entirely ouned by another operating company, It is only the non-reporting proprietarea to which reference is made when statistics are eiven for "propreta" companies In recent preprietarica


ind and $a$ few other facts were filed. They include intrastate roads and roads under construction, mileage,

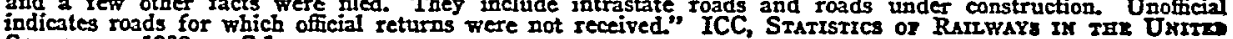
indicates roads for which of

StATzS Fol 1938, p. S-1.

Includes operating, lessor, proprietzry, circular, and unoficial companies

- Figures omitted since "miles of road" of these companies is not comparable with that of line companies.

- Excludes proprietary companies in systems which file consolidated reports combining the mileage, investment, and other items on a net system basis.

Excludes 39 miles in Canzda, 732 in Alasks, and 200 in $\mathrm{Hawati}_{2}$

- Includes 1,396 miles in Canada; cxcludes 729 miles in Alaska atri 219 in Hawaii.

The first railway companies were, without exception, small and weak measured by our present standards, and had only local interests and importance. Quite naturally, it early became clearly manifest that to give improved service at lower costs and to develop earning power for the capital which had created the properties, it would be necessary to enlarge the scope of operations so that the mileage and traffic of a considerable area, and between logical termini, would be concentrated into a unified corporate group, instead of being diffused among myriad parochial lines.

It follows that the number of companies owning railway mileage has been continually shrinking as corporate simplification has gone on through the years, in spite 
of the additions of new companies created to facilitate the construction of whatever new mileage has been built each year. Very few companies have actually built as much as I,000 miles of a railroad, yet many own more than that. Virtually all American railway companies, whether large "parent company" operating units, or merely small lessor or proprietary companies, include some mileage which was built by predecessor companies. Furthermore, much of this mileage has passed successively through the ownership of different companies, incident either to consolidation or reorganization, or a combination thereof. Hence the number of railroad companies which have actually existed in the 117 years of American railway history has been legion and their capital structure and corporate relationships have embodied almost every conceivable financial pattern and device.

In the case of each of the largest systems, many predecessor companies, in some cases up to 600 , have at one time or another owned parts of the property, or held the franchises for the construction of the lines. Today ownership of these same lines may still be distributed among more than a hundred corporations, but they are nevertheless operated as a unit with a consolidated operating account.

The corporate structures of some of the larger railway systems of the United States may be summarized as follows:

TABLe II

\begin{tabular}{|c|c|c|c|c|c|c|c|c|c|c|c|c|c|}
\hline $\begin{array}{l}\text { Railroad } \\
\text { (ranked in order of } \\
1938 \text { gross revenues } \\
\text { of parent company) }\end{array}$ & 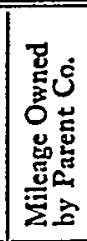 & 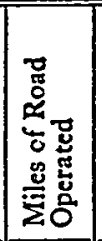 & 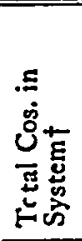 & 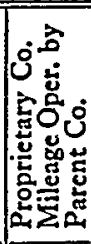 & 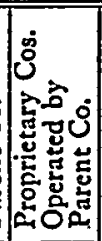 & 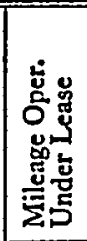 & 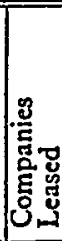 & 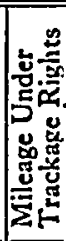 &  & 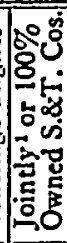 & 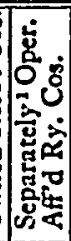 & 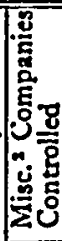 & 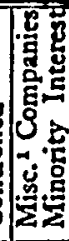 \\
\hline $\begin{array}{l}\text { Pennsylvania }{ }^{2} \ldots \\
\text { New York Central } \\
\text { Southern Pacific }{ }^{2} \\
\text { A., T. \& San. Fe.. } \\
\text { Union Pacific. ... } \\
\text { Baltimore \& Ohio. } \\
\text { Chesapeake \& Ohic } \\
\text { Chi. M. St. P. \& P } \\
\text { Chicago, Bur. \& Q } \\
\text { Illinois Central... } \\
\text { Southern } \\
\text { Chicago \& N. W Wes } \\
\text { Missouri Pacific.. } \\
\text { Great Northern... } \\
\text { Chicago, R. I. \& P } \\
\text { Norfolk \& Western } \\
\text { N. Y., N. H. \& H. } \\
\text { Eric ......... } \\
\text { Northern Pacific.. } \\
\text { Reading. ........ }\end{array}$ & $\begin{array}{r}2,943 \\
3,713 \\
1,469 \\
7,191 \\
3,554 \\
2,491 \\
2,762 \\
9,896 \\
8,644 \\
2,209 \\
4,116 \\
8,107 \\
6,262 \\
7,512 \\
5,075 \\
2,163 \\
1,174 \\
1,093 \\
6,417 \\
581\end{array}$ & $\mid \begin{array}{r}10,287 \\
11,008 \\
8,656 \\
13,456 \\
9,908 \\
6,395 \\
3,113 \\
10,920 \\
8,973 \\
4,948 \\
6,559 \\
8,349 \\
7,159 \\
8,072 \\
7,857 \\
2,198 \\
1,873 \\
2,284 \\
6,721 \\
1,450\end{array}$ & $\begin{array}{r}151 \\
72 \\
50 \\
107 \\
36 \\
122 \\
19 \\
14 \\
33 \\
66 \\
91 \\
21 \\
56 \\
25 \\
44 \\
11 \\
21 \\
64 \\
21 \\
44\end{array}$ & $\begin{array}{r}380 \\
288 \\
651 \\
6,253 \\
24 \\
2,452 \\
\overline{-} \\
\overline{-} \\
1,015 \\
\frac{14}{355} \\
141 \\
\frac{21}{2} \\
\frac{239}{31}\end{array}$ & $\begin{array}{r}14 \\
3 \\
3 \\
44 \\
1 \\
36 \\
- \\
- \\
27 \\
-3 \\
\frac{4}{2} \\
\frac{4}{1} \\
\frac{1}{18} \\
2\end{array}$ & $\begin{array}{r}6,493 \\
6,179 \\
6,377 \\
2 \\
5,675 \\
1,130 \\
17 \\
533 \\
31 \\
1,518 \\
1,491 \\
53 \\
105 \\
\frac{518}{2,318} \\
668 \\
811 \\
52 \\
789\end{array}$ & $\begin{array}{r}32 \\
37 \\
9 \\
3 \\
5 \\
16 \\
2 \\
1 \\
7 \\
14 \\
25 \\
4 \\
10 \\
10 \\
7 \\
27 \\
2 \\
29\end{array}$ & $\begin{array}{r}454 \\
828 \\
150 \\
307 \\
650 \\
312 \\
336 \\
660 \\
344 \\
207 \\
489 \\
166 \\
423 \\
417 \\
443 \\
26 \\
23 \\
258 \\
251 \\
50\end{array}$ & $\begin{array}{r}66 \\
14 \\
15 \\
30 \\
43 \\
97 \\
34 \\
56 \\
54 \\
30 \\
74 \\
11 \\
82 \\
19 \\
70 \\
13 \\
3 \\
21 \\
29 \\
10\end{array}$ & $\begin{array}{r}21 \\
8 \\
9 \\
26 \\
7 \\
11 \\
4 \\
6 \\
16 \\
9 \\
25 \\
5 \\
17 \\
5 \\
21 \\
5 \\
2 \\
2 \\
6 \\
1\end{array}$ & $\begin{array}{r}18 \\
5 \\
11 \\
2 \\
5 \\
4 \\
1 \\
0 \\
1 \\
4 \\
2 \\
1 \\
8 \\
3 \\
0 \\
0 \\
4 \\
2 \\
10 \\
4\end{array}$ & $\begin{array}{r}50 \\
9 \\
14 \\
30 \\
18 \\
32 \\
10 \\
6 \\
4 \\
10 \\
35 \\
10 \\
12 \\
13 \\
5 \\
3 \\
5 \\
14 \\
3 \\
8\end{array}$ & $\begin{array}{r}16 \\
10 \\
4 \\
2 \\
23 \\
2 \\
1 \\
5 \\
2 \\
1 \\
1 \\
5 \\
2 \\
4 \\
3 \\
2 \\
1 \\
-\end{array}$ \\
\hline
\end{tabular}

tExcluding companies granting trackage righte.

1Excluding companics grating trackage righte
ISubsidiaries and affiliates of companies in these classifications are not included in this tabulation.

2The following major subsidiaries operated as part of the system named in parentheses are listed bereia as "separately operated affilipted companiez" and their separate subsidiaries and affiates are not included in the thbulation: Long Ifland Operastivania); Pittsburgh \& Lake Erie (N. Y. Central); Texas \& New Orlezas (Southern Pacific); New York, Chicago \& St. Louis, Pere Marquette (Chesapeake \& Ohio); Chicago \& Eric (Erie). The operating accounts of the Texns and New Or

R. R. are consolidated with those of the pareat company, but this is not done in the case of these other five companieh 
In order to study in detail the corporate and financial structure of each railway system, it is necessary to have a map showing the ownership of all railroad property used in its operations. This must be supplemented by a related chart which will show in separate blocks the individual capital structure of each owning company indicated on the map (except foreign lines granting trackage rights or use of other joint facilities), subdividing all security issues to show amounts held within and without the system, and company by which owned, together with details of all pledges of securities. Such a chart, if complete, will include, in addition to the carrier companies shown on the map, all non-operating affliates and separately operated carriers in which the parent company holds any investment, irrespective of whether the operations of the company in which an investment is held are conducted by an affiliated company or not. ${ }^{2}$

Every Class I railroad in the United States owns some railway mileage, except the Clinchfield, ${ }^{3}$ the Georgia ${ }^{3}$ and the Cincinnati, New Orleans \& Texas Pacific, each of which leases all lines that it operates." In addition to the mileage which a Class I railroad owns in fee, it will usually operate other mileage to which it does not hold the title. If it controls all of the voting securities of any company, the parent corporation can take over the operation of the mileage owned by its "proprietary company," without the formality of a lease and both the income account and the balance sheet of the latter can be merged into those of the former. Should a subsidiary of this class have any bonds outstanding with the public, however, some contractual arrangement must be entered into between the parent company and the subsidiary to assure full assumption of the latter's obligations, so long as its operations and accounts are merged. Further, if there are any minority stockholders, agreements must be made with them respecting the basis on which they will forego the separate determination of net income for payment of dividends by the subsidiary and relate such disbursements to the earnings of the parent company. The Baltimore and Ohio, the Santa $\mathrm{Fe}$ and the Illinois Central are the principal examples of systems in which various proprietary companies own a substantial part of the mileage operated by the parent company.

While mortgages of the parent company cannot be made a direct lien on the property of a proprietary company unless the latter company joins in the mortgage, nevertheless the former's obligations can easily be spread over the property of such a subsidiary by pledge of the latter's obligations, capital stock, or both. ${ }^{6}$ On the other hand, a subsidiary company is sometimes used lest mileage, if directly ewned by

\footnotetext{
The Railroad Division of the R. F. C. is just completing a series of maps and charts to show the details of the corporate and financial structure of all Class I railroads and Class I switching and terminal companies. A limited number of copies of these drawings for each company are available for distribution upon request.

${ }^{2}$ Unincorporated operating organizations representing the joint lessees, The Atlantic Coast Line and Louisville and Nashville Railroads.

- Bessemer and Lake Erie R. R. Co. owns a very small proportion of the 224 miles of lines which it operates, viz.: owned, 9 miles; leased, 195 miles; used under trackage contracts, 20 miles.

E.g., B. \& O. R. R. 1st Mortgage.
} 
the parent company, would come within the "after-acquired" property clauses of the parent company's mortgage. This may account in part for the Santa Fe's extensive use of such corporations in the expansion of its system.

A subsidiary or affliate in which others than the parent company hold an appreciable amount of any of its securities, either stocks or bonds, can usually be unified for purposes of operation and accounting ${ }^{6}$ only by means of a lease, since complete merger so often embodies serious difficulties of exchange and/or purchase of securities or property. In this situation, the property of the lessor is turned over to the lessee, usually for a stated period and at a specified rental. The lease is often terminable at the option of one or the other contracting parties and the rental may be wholly or partially contingent. The lessee may own all, none, or only a part of the capital liabilities of the lessor. Pennsylvania, New York Central, Delaware, Lackawanna \& Western, Lehigh Valley, Delaware \& Hudson and Erie are railroads which have acquired a large part of their operated mileage by means of leases. It will be noted that all are eastern lines. Western lines, other than the Southern Pacific and Alton, have not had any appreciable proportion of leased mileage or number of leased lines until recently, when the Union Pacific integrated its operations through lease of its four principal subsidiaries, which were wholly owned ${ }^{7}$ but had bonds outstanding. The Rock Island, Kansas City Southern, and Colorado \& Southern have each unified, or are endeavoring to unify, the operations and accounts of their respective Texas subsidiaries through leases. The Southern Pacific Company, the nation's largest system in point of mileage, originally obtained consolidated system operation through the so-alled omnibus lease of 1885 , and while its Texas and Louisiana lines are a separately operated Class I railroad, leases are the basis of unification of its "Pacific System."

Leases have the advantage of permitting the control of property without investment, by payment of rental..$^{8}$ However, as an offsetting disadvantage rental must be paid on the entire investment, usually whether earned or not, since payment of dividends on stock as well as interest on bonds of the lessor is usually guaranteed and any failure to meet such obligations entails the risk of abrupt loss of possession of the leased property. Failure to pay returns on owned property never entails risk of immediate loss of possession of the property by the owning company and deficit on debt service thereon is less apt to result in loss of the mortgaged property in reorgan-

- Except balance sheets, as is later stated.

'St. Joseph \& Grand Island, Oregon Short Line, Oregon Washington R. R. \& Nav. Co., Los Angeles \& Salt Lake.

- It is a customary provision in leases to require the lessec to advance capital needed for developing lessor's property. The lessee usually (but there are some exceptions) receives securities of the lessor in consideration of such advances.

Many leases are very valuable to the lessee which retains a substantial balance after deducting expenses, taxes and rentals of leased mileage from revenues derived therefrom and thereby obtains use of property contributing traffic to remainder of system and often providing an indispensable link for through services. The lessee can thereby produce 2 much larger income from leased mileage by operating it as a part of a consolidated system than the lessor could possibly do as an independent operation. This, then, indicates the basis of the mutual attractiveness of leases. However, leased mileage, like owned mileage, can be unprofitable or insufficiently profitable to cover rentals. 
ization, although it may ultimately cost the stockholder his equity. Accordingly, railroads which lease important mileage from other companies usually endeavor to acquire securities of the lessor companies, and frequently do succeed in controlling some or all of such companies. Pennsylvania Railroad and Southern Pacific are notable examples of parent systems which control their leased lines. Through the acquisition of control of lessor companies, the net cost of rentals is reduced, and by so reducing the proportion of securities held by the public, a form of limited insurance against loss by default is obtained. ${ }^{\nexists}$ If a modification of any lease has to be negotiated in the event it proves impossible to carry out present terms in future years, it is much more satisfactory to deal with a controlled lessor than an independent lessor, even though courts will always protect a minority against a majority with an adverse interest. It is also important to note that capital liabilities assumed through fixed rental obligations, no matter how large, never appear on the balance sheet.

In addition to the property which a railroad operates itself (whether leased or owned in fee by itself or by a company which it controls) a large system will use much property jointly with other carriers, some as a tenant, under a trackage or joint facility contract, and some as a joint owner. The fee to small parcels of property or lengths of track is held jointly, whereas the title to larger joint investments in fixed property, particularly terminal companies, is vested in a separate company, the stock of which is jointly held.

Cooperation in the construction, ownership and operation of freight and passenger terminals has long been an accepted fact, and in nearly every large city one or more of the companies owning terminal properties have been created to provide for the needs of two or more operating companies.

In addition to the carrier companies, there are numerous corporations created to perform a variety of functions which go to make up the complete corporate structure. Some of the more familiar types are land, coal, timber, water, refrigerator car, hotel and townsite companies. Vast properties were handled by such non-carrier companies in the early days of railroad development. There were r32,425,574 acres of land given to the railroads by the federal government. To obtain these grants the railroads built 17,627 miles of track. ${ }^{10}$ Practically the entire sale of this land was handled by land and timber subsidiaries of the companies receiving the grants. Townsite companies organized by railroad companies aided the development of many western towns:

Non-carrier affliates have also been incorporated to perform certain specialized services for the systems of which they become a part. Furthermore, by placing in such corporations property not actually necessary for railroad purposes, these assets may be held free of the railroad's mortgages. This is often a desirable arrangement,

- This may also be considered as 2 method of setting up a depreciation reserve against any future diminution of operating profits from leased mileage.

${ }^{10}$ Not only did the government thus encourage the development of the interior through the building of railrosds, but it received substantial concessions in the form of reduced rates for movement of freight troops and mail, which continue to this day and not only affect the "land grant mileage" but other lines which must "equalize" to obrain competitive business. 
because, among other reasons, the sale and transfer of the property can be more quickly and economically concluded, when there is no necessity of securing releases from mortgage trustees.

There are $13^{8}$ Class I railroads operating in the United States. Nearly all have interests in property of other companies on one or another of the foregoing bases of use. These Class I companies are not all completely independent units. Many own stock control of others, either individually or jointly, and the management of such affiliates may be closely or not at all unified. Moreover, holding companies own controlling interests (not necessarily a majority) in the stock of some Class I railroads. The foregoing relationships as found in Class I railroads are tabulated below. ${ }^{12}$

It has been noted that the financial and corporate structures of most present-day railway systems are exceedingly complex. The reader, having been carried through those complexities, naturally wonders why they must remain so.

Necessarily, corporate structures can be simplified only through a reduction in the number of separate corporations comprising a system-by merger or consolidation. Many consolidations and mergers of solvent companies have been effected through the years and hardly a single reorganization has not resulted in elimination of cne or more subsidiaries as separate legal entities. Nevertheless the irreducible minimum is far off and further simplification is most desirable. Perhaps a better realization of the obstacles standing in the way of that simplification may hasten their ultimate removal.

One of the chief difficulties arises from the differences in the financial condition of the companies to be merged. It is not always easy to find a common denominator for the exchange of securities even if one of the units is a controlled subsidiary of the other, and the purchase of securities or property for cash is often difficult to fi-

12

Tabe III. Number of Class I Steni Rallways in the United States

\begin{tabular}{|c|c|}
\hline $\begin{array}{l}\text { Roads not } \\
\text { in default, } \\
\text { Bankrupty or } \\
\text { Receivership }\end{array}$ & $\begin{array}{l}\text { Roads } \\
\text { in default, } \\
\text { Bankruptcy or } \\
\text { Receivership }\end{array}$ \\
\hline 21 & 10 \\
\hline $8^{\circ}$ & 5 \\
\hline$x 8$ & $2^{\circ}$ \\
\hline$x_{3}$ & 13 \\
\hline xg & XI \\
\hline $\mathrm{xI}$ & 3 \\
\hline 2 & - \\
\hline 2 & $=$ \\
\hline 94 & $\frac{44}{13^{8}}$ \\
\hline
\end{tabular}

Independent operating companies in which no holding company or other



Independent operating companies in which important minority interest is beld by another railroad or a holding company...............

Railroads controlled by holding companies, public utilities or industries,

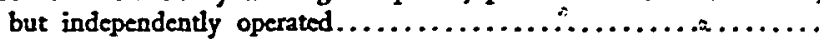

Railroads controlled by another railroad but independentily operated......

Railroads controlled by another railroad and operated as part of its system

Railroads in which majority interest is held by two or more railroads but which are separately operated. $\ldots \ldots \ldots \ldots \ldots \ldots \ldots \ldots \ldots \ldots \ldots$

Railroads in which majority interest is held by more than one railroad but which are operated as part of the system of one of the proprietary

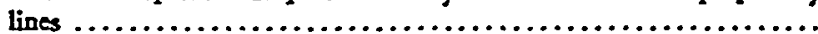

Independent operating agencies representing lessees..............

Total

Grand Total

Norx: Total Class I railways shown above prill not agree with total sbown in Table I duo to the elimination of certain companies and tho addition of others since 1938. 
nance. If the company to be eliminated has earning power or credit materially below that of the company which would absorb it, and vice versa, obvious problems arise.

Many present-day railway companies were granted charters carrying special privileges which will die with the charters. But for this, such companies, most of which have long since lost all other separate identity, could be eliminated.

Finally, it must be remembered that no large railway system today confines its operations within the territory of one state; and the very fact that one or another of the states through which a system operates has outmoded corporation laws or grasping tax statutes in effect may compel the system to retain separate corporate entities which otherwise have no reason for being. The statutes of Texas, which ranks first in aggregate length of railway mileage, require that all of this be owned by companies incorporated and maintaining their operating headquarters in the state. This is an important factor in causing the separate existence of many railway corporations.

The average investor has but four major sources of data ${ }^{12}$ about a railroad-its map, its timetable, its monthly financial statements and its annual report. The last is developed around an income account and balance sheet as a base. The former summarizes the revenues and expenses, computes the net raiiway operating income derived from all of the transportation property directly operated or used by the parent company, i.e., its owned lines, its proprietary lines, its leased lines and its trackage rights. Also the "other income" recorded in the statement sets forth the return from all other properties and investments.

A balance sheet records the assets and liabilities of the company to which it pertains and shows no financial information respecting leased lines except the book value of any of its holdings of stocks, bonds, notes of, or advances to, its lessor companies. The lessor's own obligations are shown on its own balance sheet although the lessee's guaranties may be summarized in its annual report. However, the financial condition of a lessor company can only be determined by studying its own balance sheet.

A proprietary company's assets and obligations may or may not be completely unified in the parent company's balance sheet, as the latter may merely list its investment therein, which can appear, with the I. C. C.'s permission, as an investment in property or an investment in securities. Investments in jointly owned companies appear as investments in the securities of affliated companies. The book value of properties used under trackage and joint facility contracts, and the tenant's obligations thereunder, cannot appear in a balance sheet.

The income account and balance sheet of most industrial corporations are virtually Siamese Twins since the balance sheet includes all of the assets used in producing the results set forth in the income account. For a large railroad, this, unfortunately, cannot be the case, since a carrier, as previously stated, uses much property in consideration of which it has incurred many guaranties that are equivalent to an assumption of capital liabilities, yet neither these assets nor these liabilities are shown on its own balance sheet.

Is Its weekly carloading statements issued through the Ass'n of American Railroads and miscellaneous data published by the I. C. C.'s Burcau of Statistics are also valuable. 
This brings up the question of preparation of a consolidated balance shect to embrace all of the assets and liabilitics of the many separate corporations comprising a single system. Serious accounting and corporate difficulties stand in the way. Those who have sufficient knowledge of railroad accounting to understand the distinction between a consolidated system balance sheet and a similar statement of the parent company, appreciate some of the limitations of the former and make proper allowance therefor. They probably would prefer to use the parent company balance sheet alone and examine the accounts of the subsidiaries separately, than have a consolidated account, if this should be issued in lieu of the parent company's individual statement. Since consolidated balance sheets may be confusing to some and are difficult to prepare, they have not been issued and the most useful single one, ie., the parent company's, is published.

It would be difficult to standardize accounting rules for the preparation of consolidated system balance sheets and for a regulated industry all accounting practices should be standardized. This may explain why none has been regularly required as a routine procedure by the Commission. ${ }^{13}$ It is, however, very desirable to have all of the railroad's assets used in producing its transportation income and the liability incurred in securing the capital creating the properties set forth in a single balance sheet or as few as possible. Since it will always be difficult to prepare a consolidated balance sheet bringing together the assets and liabilities of a great many individual companies with varying types and degrees of control, the desired end can only be satisfactorily achieved by avoiding a consolidated balance sheet through com. plete merger of system companies except jointly operated terminals. The simplification of accounts is another reason to look forward to the further simplification of corporate structures. Only in this way can all of the accounts be made clear, complete, understandable, and meticulously accurate in their implications. At best consolidated balance sheets are mere statistical compilations.

We have seen that the present day corporate and financial structures of the nation's railway systems, great and small, are labyrinthine mazes into which the potential investor hardly dares to venture without carefully drawn maps to guide him. We know that the complexities encountered are hang-over devices, originally conceived to preserve the continuity of earnings, which have long since lost that signifcance and have become handicaps to be overcome. It is the declared policy of the government that our railway systems need more intensive consolidation and coordination. ${ }^{14}$ Pursuant to a Congressional mandate the Interstate Commerce Commission has determined the line that future consolidations should take and has set the ultimate goal. ${ }^{15}$ The obstacles that beset the path are known, and it is to be hoped that the Congress, by appropriate legislation, the legal and banking fraternities, by the disavowal of antiquated taboos, and the investing public, by the adoption of a realistic attitude, will shortly remove these barriers from the path of the much needed simplification of the corporate structure of the great railway systems of the United States.

\footnotetext{
18 The I. C. C. has been studying the question for some time.

34 Transportation Act, 5407,41 STAT., 481 (1920), 49 U. S. C. $55(4)$.

${ }^{28}$ Consolidation of Railroads, 63 I. C. C. 455 (1921).
} 